Ethics, Place and Environment, Vol. 3, No. 2, 187-201, 2000

\title{
Urban Development on the Basis of Autonomy: a Politico-philosophical and Ethical Framework for Urban Planning and Management
}

\author{
MARCELO LOPES DE SOUZA
}

Original manuscript received, 17 May 1999

Revised manuscript received, 21 July 1999

\begin{abstract}
Urban development is seen in this paper as the process of achieving more social justice in the city through changes both in social relations and in spatiality. Autonomy, in the sense used by Cornelius Castoriadis, is here regarded as the main parameter for the evaluation of processes and strategies for positive social change. Nevertheless, the Castoriadian philosophical notion of autonomy must first be made operational before it can be reasonably applied in empirical research or policy evaluations. The aim of the paper is to contribute to this operationalisation, specifically considering the role of urban planning and management in the realisation of urban development.
\end{abstract}

\section{Introduction: the Autonomy Project and the Question of its Implementation}

Urban development is a somewhat uncomfortable notion, due to its usual association with the capitalist ideology of modernisation. Urban growth is quite often considered uncritically as a sign of urban development, in a way which corresponds to a banalisation of the idea of social development. Not only in the realm of common sense, to develop a town or city means to make it larger, more sophisticated, more 'modern', in the name of 'progress'; not to mention that, at least in the Anglophone world, new buildings are usually called 'developments'. Also in the planning literature, the mere transformation of land in a built environment is generally termed 'land and property development'.

In contrast to the capitalist modernisation ideology, social development is seen in the present paper as the process of achieving more social justice through changes both in social relations (institutions, laws and norms) and in spatiality (from the spatial structures in a material sense to the territoriality and the image of places). However, my

Marcelo Lopes de Souza, Universidade Federal do Rio de Janeiro, Departamento de Geografia, Núcleo de Pesquisas sobre Desenvolvimento Sócio-Espacial, Prédio do CCMN, bloco 1, Cidade Universitária-Ilha do Fundão, 21941-590, Rio de Janeiro/RJ, Brazil. E-mail: tula@igeo.ufrj.br 
political, ethical and theoretical background is not historical materialism but, rather, the autonomist approach of Cornelius Castoriadis.

According to Cornelius Castoriadis (1922-1997), co-founder of the famous French left-wing journal Socialisme ou Barbarie and one of the most profound and original social and political thinkers of this century, representative democracies are, in reality, 'liberal oligarchies' which embody a structural gap between a minority of powerful groups and the majority of ordinary citizens: decision-making spheres are largely closed off from public and democratic accountability; information which is brought to the public is usually masked; and the state guarantees the reproduction of the existing social and economic order through its legal monopoly of violence. Marxism, in Castoriadis's eyes, was not able to propose a deep alternative to capitalism and representative democracy. In Marxism, resistance against the structural inequality of the distribution of the wealth generated by society provoked criticism of capitalist production relations, but typically not a criticism of productive forces brought about by the capitalist mode of production. The development of mankind would necessarily include the utilisation of the technological legacies of capitalism, which in themselves should be regarded as positive; the great and actual problem would involve direction by the wrong hands and in the wrong way-a misfortune, which was to be eliminated by the revolutionary working class, led by the communist party. Even regarding capitalist relations of production and the political 'superstructure' which contributes to their maintenance, the Marxist alternative was very limited from a radical-libertarian standpoint: the question of the organisation of production in a 'socialist' society remained full of contradictions, and doctrines and strategies like Leninist 'democratic centralism' and the idea of a 'socialist state' established through a 'dictatorship of the proletariat' reveal Marxism's authoritarian dimension. As Castoriadis showed, all of these problems are symptoms of the presence of capitalist 'social imaginary significations' in Marxist thought. ${ }^{1}$ This problematic did not begin with Stalinism, nor even with Leninism; some problems which became worse and more explicit later can be found in the writings of Marx himself (Castoriadis, 1975, 1978, 1985).

From a politico-philosophical standpoint, the apex of Castoriadis's multifaceted intellectual work was a seminal contribution to the re-establishment of the democratic project-the autonomy project. In this he was inspired by the classical Greek heritage regarding direct democracy, whilst supporting his case with a charge against the structural limits of modern representative democracy and, at the same time, a refutation of Marxism. Castoriadis certainly recognised that ancient democracy lacked universalism and he did not ignore slavery as the central weakness of the Greek polis. Notwithstanding this restriction, ancient Greece saw not only the 'co-birth' of philosophy (i.e. of the explicit questioning of tradition) and politics (i.e. of the explicit deliberation about, as well as the lucid attempt to change, laws and institutions), but also the birth of autonomy.

The idea of autonomy embraces two interrelated senses: collective autonomy, or the conscious and explicitly free self-rule of a particular society, as based on politico-institutional guarantees as well as the effective material possibility (including access to reliable information) of equal chances of participation in relevant decision-making processes; and individual autonomy, that is the capacity of particular individuals to make choices in freedom (which depends both on strictly individual and psychological circumstances and on political and material factors). An autonomous society is one which 'institutes' itself on the basis of freedom both from metaphysical constraints (e.g. religious foundations of laws and norms) and from oppression (Castoriadis, 1983, 1986a, 1990, 1996a, 1997).

For Castoriadis, despite the rich experience and the important lessons learned from the 
history of the workers' movement, no class or group should be regarded as absolutely privileged in relation to the task of building a more just, autonomous society. Overcoming class exploitation in the sphere of production was considered by him as a major challenge, but not necessarily as more important than the tackling of other problems, like oppression along gender and racial lines and the anti-ecological nature of capitalism. Consequently, he paid great attention to the political contribution of the so-called 'new social movements', while refusing a narrow and economistic class struggle perspective (Castoriadis, 1985).

Autonomy is here regarded precisely as the central principle and parameter for the analysis and evaluation of processes and strategies of social change, including urban development. Nevertheless, admittedly, the Castoriadian concept of autonomy must first be made operational, before it can be substantially effective for concrete purposes in empirical research or policy evaluations. Castoriadis himself did not work on this task, as his attention was so heavily concentrated on charting a radically alternative field (the autonomy project) from a philosophical point of view. However, making the autonomy project operational is an unavoidable task, both from a scientific (in the sense of empirical research) and from a practical political perspective.

The aim of this paper is to contribute to this operationalisation, specifically considering the role of urban planning and management in the realisation of urban development. After this task is addressed in the second section, the third section compares the presented autonomist approach with two current approaches to urban planning and management in the Anglophone world. The fourth section discusses the main characteristics of the Brazilian concept of 'urban reform' and its extension in the form of 'new master plans' and 'participatory budgeting', in relation to which my approach aims to be a further development. The two approaches briefly examined in the third section'communicative planning' and 'Rawlsian planning' — as well as the Brazilian approach, were selected by virtue of their progressive nature. The Brazilian context is of particular interest because it has exhibited certain strategies and experiences which are even more ambitious than many schemes of citizen participation in urban planning and management in the 'First World'.

\section{Autonomist Urban Planning and Management: Making the Utopia Operational}

Doyal and Gough's (1994) contribution to a 'theory of human needs' comprises a useful and quite concrete definition of individual autonomy, although they pay inadequate attention to the constraints of real individual autonomy within representative democracy and capitalism. According to them, a person's autonomy essentially depends on the following three things: first, the 'degree of understanding that an individual has about himself [sic], about his culture and about the expectations which are addressed to him as a member of his society'; secondly, 'his psychological capacity to formulate options for himself'; and thirdly, the 'objective opportunities for action on this basis' (Doyal and Gough, 1994, p. 90).

Now the vital issue is thus whether a particular society is more or less heteronomous or autonomous (collective autonomy), because strong individual autonomy in a proper sense will be a fiction - at least, as far as the majority of the population is concerned-in the framework of a society which is characterised by structural asymmetry in the distribution of power and by inequality regarding the opportunities for the satisfaction of needs, all this being associated with economic privileges and sanctioned by the social imaginary. Precisely here, Castoriadis (1983; 1986a, b; 1990; 1996a, b; 1997) provides us with the right interpretative context for the aforementioned conditions. Of course, 
'autonomy' has always been a major theme in political philosophy, from classical liberals to Rawls and to even more recent contributions like David Held's (1996) notion of 'democratic autonomy' (which corresponds, indeed, to a kind of improved social democracy). However, Castoriadis's work represents the best attempt yet to discuss genuine autonomy as individual and collective autonomy simultaneously, considering all its political, material and cultural prerequisites and implications.

It seems desirable at this point to explain briefly why autonomy deserves the role of a central principle and parameter, before turning to consider the operationalisation of this concept. Deprived of the dimension of autonomy, urban development can only be, in the best of all cases, mitigated social oppression and inequality: a kind of modernisationcum-reduction of poverty and environmental damage, conducted by enlightened ruling elites. Despite the gains in terms of the mitigation of environmental destruction, poverty and residential segregation, such a state of mitigated oppression cannot meet a fundamental prerequisite for a genuine process of social development: substantial gains in terms of freedom. There is no reason to assume that professional politicians and their 'experts' (managers and planners) necessarily know what is good for individuals and groups better than the individuals and groups themselves. What is at stake here is not technical competence (the ability to choose the most efficient means in order to achieve given ends), but freedom: who decides about the ends? Can 'experts' and so-called 'representatives' legitimately define the needs of ordinary men and women in the place of the citizens themselves?

At least within the Western cultural context, and despite the observation that autonomy as a latent value co-exists, within Western and strongly Westernised countries, with the political apathy which is indirectly stimulated by the system of representative democracy, autonomy possesses both an intrinsic worth (enjoyment of liberty as the necessary basis for self-esteem and self-realisation) and an instrumental worth (autonomy for doing things, for trying to overcome problems). In this light, a just society can be understood as one in which laws, norms and institutions ensure citizens equal access to decision-making regarding the regulation of public affairs. That is, laws, norms and institutions have to ensure the autonomy of the individuals and of the society. Surely, the use of specific indicators of social welfare is a necessary step in every empirical evaluation of concrete situations. On the other hand, as the contents of ideas such as 'quality of life', 'basic needs' and even 'justice' are neither independent of particular cultural and historical contexts nor legitimately separable from the expectations of those whose quality of life should become better, whose basic needs should be satisfied and who want to live in a just society, the use of specific indicators is ethically illegitimate unless they are defined, and the achievement of goals is monitored, through citizen participation.

Be that as it may, the process of constructing autonomy is not an all-or-nothing matter. Seen in such light, this process appears as a necessary compromise between, on the one hand, a strategic level of thought and action (that is, a 'utopian' or radical 'horizon') and modest tactical victories here and now on the other hand (this point has been already stressed in Souza, 1996, 1997, 1998). Bearing this in mind it is possible, now, to offer a first step towards the conversion of Castoriadis's philosophical notion of autonomy into more operational concepts.

Autonomy (both collective and individual, which are two sides of the same coin) should be understood as a subordinating parameter, as the democratically most legitimate way to achieve more social justice, and a better quality of life is when the individuals and specific groups themselves define the concrete contents of development (goals and standards) in the context of their 'lifeworlds'. We can consider social justice 
and quality of life as two major subordinated parameters, i.e. subordinated to autonomy as a principle and parameter. As far as economic efficiency is concerned, it is not considered here as a goal in its own right; it is just a means which has to serve the improvement of social justice and quality of life, and only in this case is economic efficiency morally legitimate from an autonomist perspective.

More social justice and a better quality of life are essential aims; however, they are also very abstract constructs. In fact, they have to be treated as general subordinated parameters which need to be supplemented by particular subordinated parameters. As social justice and quality of life are connected to different spheres (whereas social justice is related to the public sphere, quality of life is mainly related to the private sphere; nevertheless, the preferences and possibilities of individuals and households are influenced and conditioned by processes and institutions at the level of society), we have to identify two kinds of particular subordinated parameters. Examples of particular subordinated parameters associated with social justice are the level of residential segregation, the level of socio-economic inequalities and the degree of opportunity for direct participation in relevant decision-making processes. Examples of particular subordinated parameters associated with quality of life are those related to individual satisfaction in terms of health, education and so on.

My own theoretical approach to social (or, as I prefer, socio-spatial) development, under the inspiration of Castoriadis's philosophical thought, is basically procedural, not substantive: the contents of development have to be defined by the people themselves (Souza, 1996, 1997, 1998). Thus, the specification of the particular subordinated parameters should be understood not as a task for intellectuals and planners alone, but as a collective task at the level of society as a whole. However, some preliminary comments regarding the degree of opportunity for direct participation in relevant decision-making processes can be offered here.

On the one hand, the opportunity for direct participation in the making of decisions which affect the regulation of collective life can be understood as one of the particular subordinated parameters. On the other hand, though, it deserves a different and very special place among the particular parameters, as it corresponds to a direct 'translation' of the core of autonomy itself (which has an instrumental as well as an intrinsic worth) into a more concrete level at which 'measurements' on an ordinal scale are possible. Arnstein's (1969) famous 'ladder of citizen participation' can be helpful in this 'translation'. She identified eight 'steps' towards real citizen participation: from manipulation (1) and therapy (2) to partnership (6), delegated power (7) and citizen control (8) via informing (3), consultation (4) and partnership (6). Only (6), (7) and (8) represent, according to her, degrees of real citizen power; (3), (4) and (5) correspond just to degrees of tokenism, while (1) and (2) represent non-participation. These categories are still very useful; putting them into my own Castoriadian conceptual framework, it is possible to say that Arnstein's 'citizen control' corresponds to strong collective autonomy, whereas 'manipulation' represents a very regrettable situation in terms of heteronomy. Of course, Arnstein's ladder is narrower than the actual spectrum of possible socio-political situations. Complete autonomy, in Castoriadis's sense, corresponds to stateless direct democracy, while absolute heteronomy is exemplified by slavery and totalitarianism.

However, since the specification of aims according to the desires and needs of the inhabitants themselves as well as the monitoring of the right implementation of planning instruments, infrastructure and services will depend to a large extent on direct citizen control, the implementation of planning instruments and zoning proposals should be supplemented by the creation of councils for urban development, which have decision- 
making power and to which representatives, both of the state and, above all, of the civil society, belong. The councils for participatory budgeting which have been implemented in the context of some Brazilian experiences of popular participation in the budgeting process, as paradigmatically illustrated by the case of Porto Alegre (see below), can be taken here as an important example of delegated power within the general framework of representative democracy. They should be viewed as a possible source of inspiration for even more advanced experiences in the future, not only in Brazil, but also in less heteronomous societies.

\section{Comparative Background: Two Current Approaches to Urban Planning and Management in the Anglophone World}

\section{Planning as a Communicative Enterprise}

Urban planning (and management) conceived as a 'communicative enterprise' have been discussed by Healey $(1995,1996,1997,1998)$ and Innes (1995), among others, under the inspiration of Jürgen Habermas's philosophical reflections on communicative rationality and action.

For Habermas it is possible, within the context of communicative action-the process of giving and criticising reasons for holding or rejecting particular claims-to arrive at voluntary agreements for the sake of co-operation. Habermas (1981, vol.1, p. 28) situates both rationality and ethics within a communicational context, believing in the 'power of consensus-creating argumentative conversation'. For him, the instrumental rationality (kognitiv-instrumentelle Rationalität), which deals with instrumental disposal (instrumentelle Verfügung) and the optimisation of means, is far from being the only type of rationality. Communicative rationality (kommunikative Rationalität), which flourishes through communicative action (kommunikatives Handeln) and can be the fundament of rational discussions of ends, is not a less important form of reasoning. Whereas the context of instrumental rationality is 'strategic action' (strategisches Handeln), which is oriented to efficiency, usually embodying a dimension of domination and manipulation, communicative rationality is oriented towards communicative understanding (kommunikative Verständigung).

As far as 'communicative planning' is concerned, its typical weakness has been the lack of attention to the fact that some conflicts of interest (for example, due to objective class contradictions) cannot be overcome simply (or totally) through 'communication'. Commitment to discourse ethics is crucial from a point of view which refuses authoritarian strategies of a Leninist style, but it is not a panacea: it would be unrealistic to expect that a substantially more just society can be constructed exclusively through consensus. Moreover, the very existence of deep inequalities makes communicative action difficult. Communicative action can contribute to the achievement of more autonomy, but, dialectically, at the same time, a certain degree of individual and collective autonomy is a prerequisite of communicative action. Yet it would be unfair to blame Habermas for this weakness. He is quite aware, probably more than most 'communicative planners', that a dialogical form of practical reasoning demands freedom and equality. Consensus in a proper sense can be achieved only on the basis of free participation of all participants: one cannot expect the consent of participants ' $[\mathrm{u}]$ nless all affected can freely accept the consequences and the side effects that the general observance of a controversial norm can be expected to have for the satisfaction of the interest of each individual' (Habermas, 1990, p. 93).

Despite the fact that progressive urban management hic et nunc-that is, in existing 
class societies-must be a 'government for all', the recognition of structural inequality as a feature of capitalist societies should lead, on the part of a progressive government, to a 'disadvantaged people perspective'. Without the establishment of the satisfaction of the needs of the least advantaged as well as the reduction of inequalities as clear priorities, a plea for 'collaborative planning' on the basis of communication (Healey, 1997, 1998) remains prone to conservative instrumentalisation. Either the purpose of 'collaboration' is the reduction of tensions and the overcoming of prejudices between different interest groups in the context of a style of governance which treats the achievement of greater social justice as the highest priority, or 'collaboration' is nothing more than an unrealistic harmonious dream, which can contribute to the ideological legitimation of the capitalist view of urban development and to the stabilisation of a style of governance which serves above all the interests of the dominant groups. From a Castoriadian point of view, 'communicative/collaborative planning' seems to be a weak alternative both to conservative planning and to Marxist approaches to social change and development.

\section{Rawlsian Planning}

Another approach which is worth noting is McConnel's (1995) 'Rawlsian planning theory', which finds its source of inspiration in Rawls's (1972) theory of 'justice as fairness'. McConnel pleads for urban planners to be committed to the needs of disadvantaged social groups, a first priority from an ethical viewpoint.

Rawls (1972, p. 516) understands autonomy, in principle, as personal freedom: 'acting autonomously is acting from principles that we would consent to as free and equal rational human beings, and that we are to understand in this way'. His conception of 'justice as fairness' is, as he himself admits (Rawls, 1972), individualistic. On the other hand, he is surely not so radically individualistic as other liberals in protecting individual autonomy (and above all, the property rights of dominant classes and groups) at the expense of the rights of minority or least advantaged groups. He is opposed, for instance, to utilitarianism, which seeks a maximisation of total social welfare without considering appropriately the problem of inequality (for example, the fact that a greater sum of advantages can be achieved at the expense of exploitation and oppression of minority groups).

Rawls challenges both the principle of utility (maximisation of the sum of expectations), which permits compensation for the losses of some by the gains of others, and the notion of 'liberal equality', which permits the distribution of wealth to be determined by the natural distribution of talents ('natural lottery') — what is morally arbitrary. Nevertheless, he is weak in his criticism of classical liberalism. His second principle of justice ('the difference principle') ${ }^{2}$ lacks immunisation against some types of structural heteronomy, for instance capitalist class divisions:

[s] upposedly, given the rider in the second principle concerning open position, and the principle of liberty generally, the greater expectations allowed to entrepreneurs encourages them to do things which raise the long-term prospects of laboring class ... Eventually the resulting material benefits spread throughout the system and to the least advantaged (Rawls, 1972, p. 78).

As other authors (e.g. Daniels, 1975) have shown, Rawls's theory justifies certain socio-economic inequalities and presupposes a low estimate of the extent to which these inequalities undermine the exercise of liberty.

Consequently, despite the advantages of a Rawlsian approach in comparison with 
utilitarian and classical liberal ones from the standpoint of social justice, it is unbalanced, in so far as (mirroring other liberal approaches) it does not adequately deal with the problematic of collective autonomy. The result of this is that its potential for 'appraising existing institutions as well as the desires and aspirations which they generate' (Rawls, 1972, p. 520) is rather limited from a Castoriadian viewpoint. A Rawlsian perspective is suitable for the task of improving the quality of life of disadvantaged groups within the existing capitalist societies, but it does not challenge some structural constraints on individual autonomy which are related to the intrinsically heteronomous nature of representative democracy and capitalism. Castoriadis provides us with a deeper reflection about the social conditions for individual freedom, as he understood much better than the liberals the interdependence of individual and collective autonomy.

\section{Comparative Background: Brazilian Contributions}

\section{The Idea of 'Urban Reform'}

Echoing a criticism diffused by European and US-American Marxist intellectual movements during the 1970s and 1980s, Brazilian left-wing geographers and sociologists used to view planning with suspicion. Especially in a highly heteronomous, semi-peripheral country like Brazil, it was easy to demonstrate through much empirical evidence that urban planning usually serves the interests of dominant groups rather than the 'common good'. Planning in a capitalist city was considered to be an activity through which the state promotes goals which benefit the capitalists (as well as the privileged inhabitants as such) and which leads to the perpetuation or even to a deepening of residential segregation and social inequality at large.

The only problem with this approach was its over-generalising style. Partially as a consequence of Marxism's 'anti-reformism' (according to which everything that contributes to social improvements outside the framework of a proletarian revolution can just contribute to the stabilisation of the status quo and is therefore in the end 'reactionary'), and partially as a result of academicism, most left-wing scholars refused not only standard planning, but also planning as such. As far as Brazil during the 1970s and until the mid-1980s was concerned, there was a third factor in this neglect of planning: the insignificant room for progressive governance in the period of military dictatorship.

However, a pragmatic approach emerged in the mid-1980s among Brazilian left-wing scholars, who began to see the representative democratic regime which was reintroduced in Brazil in 1985 as a basis for some relevant improvements through progressive politics. These scholars and planners, along with militants from social movements, developed the idea of urban reform. In the contemporary parlance of Brazilian progressive scholars, urban reform (reforma urbana) means not simply an intervention aiming at spatial restructuring, but a social reform which encompasses a spatial dimension and whose scope is a transformation of the institutions which regulate power and the production of space, in order to achieve more social justice. It corresponds, therefore, to an antipode of conservative reforms of the city's physical design, for instance in the style of the old US-American 'urban renewal' strategy.

The making of a new, democratic constitution for the country after more than 20 years of military rule was regarded by left-wing intellectuals and militants as an opportunity to intervene in the public scene to put forward an urban reform at the national level. The National Movement for Urban Reform was set up in order to influence the Congress. According to a legal rule passed in July 1987, civil society had the right to present 
proposals for constitutional amendments to the new constitution, provided at least three organisations and 30000 voters supported the proposal. In 1987, urban social movements and various professional associations gathered together to draw up the Popular Constitutional Amendment for Urban Reform. This amendment proposal gained the support of about 150000 voters and was presented to the Congress, which would prepare the new constitution.

However, there was a problem: according to this legal rule, the Congress needed only to receive the proposal: it was not mandatory for the Congress to follow it. In fact, the popular amendment was disfigured in the course of the debates in the Congress, so that only fragments from the original proposal remained in the text of the constitution (which was promulgated in October 1988). Article 182 stresses that the private ownership of urban land should have a 'social function', that is, it should not be used for speculation; but this article also determines that the municipalities themselves (with 20000 inhabitants or more) have the responsibility for the definition of the norms and parameters, through the master plans for urban development, according to which the 'social function' could be granted. The mention of planning instruments like taxation of land and property at progressive rates and expropriation is vague and incomplete in this article.

Although this was not a complete defeat for the National Movement for Urban Reform, the mobilisation for such a reform was no longer a battle at the national level in the proper sense; the real 'battle front' was essentially transferred to the local level.

\section{The 'New Master Plans'}

For left-wing scholars, who were accustomed to see local master plans as technocratic instruments in the hands of conservative and/or ineffective local administrations, reshaping this instrument in order to transform it into a tool for urban reform at the municipal level has been a challenge. Ribeiro and Cardoso's (1990) paper, in which the conceptual, theoretical and political bases of the 'new master plans' were well synthesised, was one of the pioneer works in this respect.

The most distinctive characteristic of conventional planning is its technocratic character. Conventional urban planners see participation of ordinary people in the planning process as undesirable. Planning is understood as a purely technical matter which has to be carried out on the basis of rationality; ordinary people who are not appropriately trained have to submit themselves to specialised knowledge. Of course, rationality is interpreted by these planners exclusively in its instrumental sense of taking the most effective means to given ends. Typical conventional planners see themselves as valuefree professionals. The discussion of the ends, as a discussion of values, is seen as pertaining to a 'non-rational' realm; at the same time, capitalist modernisation (and related values like order and efficiency) is accepted uncritically as a consensual and predetermined aim.

In contrast, alternative planners' first priority is social justice. Modernisation is not a priority in its own right, and the existence of deep social contradictions is not masked. While conventional planners' ideological background is a classless notion of the 'common good' (which is typical of the utilitarian and liberal tradition), aiming at a well ordered city, alternative planners aim at a more just and democratic city. Alternative planners stress the importance of popular participation, viewing planning as a politicaltechnical process, not just as a technical product (the master plan) or even as a technical process. During this process, the aim of the planner is not to build harmony through technical rationality, conceiving disharmony as a fully avoidable and pathological thing, but to make explicit the conflicts and to try to regulate them with the help of political 
transparency and the political participation of the affected citizens (Ribeiro and Cardoso, 1990).

While conventional urban planning deals with projections towards an ideal city, in the context of which the illegal and informal parts of the actual urban space (shanty towns and irregular working class settlements) are usually ignored, alternative urban planning deals with the real city, and its priority is not to project ideal 'end-states' through 'blueprint plans', but to conceive tools for tackling the existing urban problems (residential segregation, land speculation and so on) in a democratic way. These tools include some planning instruments, like the progressive property tax, the betterment tax and the sale of building rights, which are not new but have not or have rarely been implemented by virtue of their 'subversive' character. Conventional planners' most important instrument for the achievement of order and efficiency is land use zoning, through which land uses are distinguished and provided for in separate zones (similar to the rooms of a house), whereas alternative planners give zoning another priority: to identify and classify spaces according to their social situation and public interest: both zones of special interest regarding social promotion, i.e. zones demanding community upgrading and/or legal regularisation, and zones of special interest regarding environmental protection (Ribeiro and Cardoso, 1990). It is well known that the roots of land use zoning lie at least partly in the purpose of segregating certain social groups. In contrast to it, in the hands of alternative planners zoning turns out to be a tool for integration instead of segregation.

\section{Participatory Budgeting}

Direct participation by civil society in the election of priorities regarding the municipal budget, which thus ceases to be a privilege of mayors and municipal deputies, is another central component of progressive urban governance. Although it contains a planning dimension, 'participatory budgeting' can be more adequately described as an urban management scheme. This means the introduction of a substantial dose of direct democracy in the system of representative democracy at the local level, giving the question of 'empowerment' of the powerless a real importance.

Even though it was not the first experience of participatory budgeting in Brazil, the real benchmark in this respect was the introduction of participatory budgeting in Porto Alegre (the capital city of the state of Rio Grande do Sul) in 1989, after the grassroots-based Workers' Party elected its candidate for mayor. Porto Alegre became the most influential experience of participatory budgeting in the country, and a point of reference for other progressive governments. ${ }^{3}$

Participatory budgeting in Porto Alegre can be briefly described as a series of meetings occurring from March to July. During this time the municipality co-ordinates two main meetings in each of the 16 administrative regions into which the city was divided ad hoc. During the first main meeting the municipality presents and explains its actions and accounts for the previous year, submitting to the attending citizens' representatives (freely elected delegates) and the population in general its plan of investments for the current year. Furthermore, it anticipates the potential financial resources for the next year. It is during the first meeting that the citizens of each administrative region also elect their delegates, proportional to the number of citizens attending the meeting. ${ }^{4}$ After the first main meeting, the delegates contact ordinary people through unofficial meetings organised by the people themselves to discuss their demands. Then, during the second main meeting, which is also co-ordinated by the municipality, the delegates choose the administrative region's priorities with respect to 
which the government should invest. During the second main meeting the Council for Participatory Budgeting is formally installed. It is formed by two councillors elected by each administrative region and two councillors elected by each thematic plenary assembly, as well as one representative of the civil servants' trade union, with another one appointed by the municipal federation of neighbourhood associations and two representatives from the government (the representatives from the government do not have the right to vote). This council has a final say on any issue related to the next budget (at least as far as the executive is concerned, since the city council still has to vote on the proposal and so the municipal legislature remains an important power source)..$^{5}$

\section{The Relevance of the Brazilian Strategies and Experiences from an Autonomist Perspective}

From an autonomist point of view, the Brazilian concept of 'new master plans' should be valued quite positively. Some general aims related to urban development in a broader social sense (i.e. increasing quality of life and social justice), which can be anticipated by the analyst with regard to his or her own society, can be met through the consistent implementation of planning instruments like progressive property tax (in order to tackle land speculation), the sale of building rights (which contributes to an increase in state revenues and can further contribute to a reduction of the land prices and building densities) and betterment tax (with the purpose of raising state revenues). Moreover, the implementation of an alternative type of zoning offers a framework for the establishment of priorities of investment of additional financial resources (obtained with the help of the aforementioned instruments, among others) according to the social situation and degree of deprivation: legal regularisation of shanty towns and semi-legal low-income settlements, community upgrading and the like.

At this point, the role of social movements should be emphasised. A well organised civil society and a tradition of mobilisation offer a better chance for the implementation of progressive plans and management schemes, since this implementation depends, to a large extent, on the effective functioning of councils such as Porto Alegre's Council for Participatory Budgeting. Ironically, several alternative planners tend to overestimate the power of plans and laws and, at the same time, to underestimate socio-political factors, such as the degree of vitality of social movements. ${ }^{6}$ The consequence of this has often been over-optimism, considering that, unfortunately, the weakness of social movements has been a characteristic in most Brazilian cities since the end of the 1980s. Precisely within the context of an urban regime 'devoted to lower class opportunity expansion' (to employ Stone's (1993, p. 20) terminology), in which there should be a strong commitment to citizen control, the degree of organisation and critical consciousness of the civil society is a crucial factor of urban governance.

However, this underestimation of socio-political factors needs to be qualified. In reality, this problem is largely restricted to the planners and academics who have privileged the 'new master plans', whilst the intellectuals who have paid more attention to participatory budgeting seem to be much less prone to this kind of underestimation. Of course, participatory budgeting is not a panacea for all urban problems; but a consistently implemented one is also far from being a superfluous instrument. Despite the fact that the percentage of the total budget set for capital expenditures is rarely larger than $15 \%$ or $20 \%$, the amount of financial resources to be decided about in the framework of participatory budgeting will not necessarily be irrelevant, provided that a large portion (or perhaps the totality) of the $15 \%$ or $20 \%$ is allocated to the sphere of 
participatory budgeting. In Porto Alegre, for example, all new investments have been decided upon through citizen participation. Furthermore, although participatory budgeting has been a source of popular support for the municipal administration (the Workers' Party has not lost elections in Porto Alegre since its first victory), the experience cannot be seen as populist or demagogic, because it encourages the free participation of ordinary citizens. They have real power in their hands, while the state, to a large extent, plays only the role of a co-ordinator. It is remarkable that participatory budgeting can precisely contribute both to a very significant reduction in the dependency of poor people on clientelistic mechanisms and to the empowerment of neighbourhood associations and civil society at large (on Porto Alegre, see Fedozzi, 1997; Abers, 1998). The fact that Porto Alegre is one of the few Brazilian big cities where urban social movements are not in crisis is surely not accidental.

Although participatory budgeting has deserved less attention on the part of most alternative planning theorists than the 'new master plans', the former is even more important than the latter. The dose of direct democracy represented by participatory budgeting is an important step towards more collective autonomy; furthermore, it can indirectly contribute to more individual autonomy, as more education, better sanitation and the like obviously contribute to an improvement of the opportunities of access to power on the part of individuals, especially the poor.

As a last remark, it must be underlined that, on the one hand, the dominant style of urban planning and management in Brazil still is very heteronomous; it only corresponds to 'manipulation' in Arnstein's (1969) terminology. However, on the other hand, there are also some local-level experiments which are even more advanced and ambitious than the usual 'participation' schemes in Europe and the USA. For example, 'participation' seems to be an important characteristic of the UK's present-day planning system, where there is a statutory obligation on the planning authority to consult the public during the preparation of local plans. However, as Adams (1994, p. 180) underlined, in the process of statutory local planning, 'participation has been narrowly interpreted by most local authorities and corresponds in practice to the degrees of tokenism (placation, consultation or informing) on Arnstein's ladder': this is the reason why he prefers to describe it 'not as participation but as consultation'.

As far as the USA is concerned, Stone (1993, p. 20) admitted that urban regimes devoted to lower-class opportunity expansion 'are largely hypothetical'. In contrast, participatory budgeting in Porto Alegre, for example, is quite real. This paradigmatic case is a largely successful realisation of 'communicative' urban management in the context of progressive governance. Moreover, Castoriadis himself, who gave lectures in Porto Alegre a couple of times and had the opportunity to know that experience personally, saw it in a very positive light (see Castoriadis et al., 1992), although his ideas have been by no means the only source of inspiration for participatory budgeting: there have been several sources of inspiration, reaching from neo-Marxism to contemporary debates on direct democracy.

\section{Conclusion}

In the context of a politico-philosophical work which was written and refined over the course of half a century, and in which he examined the weaknesses and contradictions both of capitalist ideology and of Marxism, Cornelius Castoriadis argued that real freedom and social justice need a societal framework which must be different from both capitalism (and representative democracy) and authoritarian 'socialism'. He termed this alternative the 'autonomy project'. For Castoriadis, the conscious and explicitly free 
self-rule of a particular society, as based on politico-institutional guarantees as well as on the effective material possibility of equal chances of participation in relevant decision-making processes (collective autonomy), and the capacity of particular individuals to make choices in freedom (individual autonomy), is, at bottom, not compatible with the institutions of Western 'liberal oligarchies', not even in the most advanced welfare states. That is the reason why, from a Castoriadian standpoint, all three current approaches discussed in this paper- 'communicative planning', 'Rawlsian planning' and the Brazilian schemes of alternative urban planning and management—present non-negligible limits.

Even though the mainstream of Brazilian alternative urban planning presents advantages in comparison with a weak, naive version of 'communicative planning', the underestimation of socio-political factors on the part of many 'new master plan' theorists is their Achilles' heel. Furthermore, the overestimation of the role of the institutional and legal framework on the part of many alternative planners usually accompanies the lack of a more ambitious project of social change, as if a domesticated capitalism and an improved representative democracy were good enough in terms of societal and political prerequisites for social justice. In so doing, these alternative planners do not do justice to the original radicalism of the idea of reforma urbana (Souza, 1998), and it is not clear that their position is more advanced than a Rawlsian approach. In truth, even the most radical and consistent among all Brazilian experiences of progressive urban governance, namely Porto Alegre's participatory budgeting, represents only a fascinating step towards a more autonomous society: it is not a non plus ultra in terms of autonomy.

The central task for an autonomist approach to urban planning and management in the next years is twofold. It is necessary to contribute to the critical refinement of positive strategies and experiences, such as Porto Alegre's participatory budgeting, which means that we must be able not only to discuss and suggest 'technical' improvements, but also to avoid problems such as the overestimation of the power of plans and laws, the underestimation of socio-political factors and, last but not least, the overestimation of the degree of compatibility between capitalism and representative democracy on the one hand, and social justice and citizen control on the other hand. However, we must also be able to learn from such experiences, in the 'North' as well as in the 'South', and especially from the people on the ground, in a dialogical manner. In a very deep sense, autonomist strategies of social change must be committed, above all, to communicative action and rationality, subordinating instrumental rationality and 'strategic action' (in a Habermasian sense). On the other hand, the most consequent politico-philosophical framework for communicative action and rationality is the project of autonomy in its Castoriadian sense.

\section{Acknowledgements}

The author would like foremost to thank Elizabeth Vander Meer for her stylistic suggestions. He is also grateful to the two anonymous referees for their excellent comments.

\section{Notes}

1. 'Social imaginary significations' is a concept which plays a central role in Castoriadis's philosophical work. They cannot be reduced to the Marxist concept of ideology ('false consciousness'), be properly used as synonymous with the broad anthropological concept of culture or be seen as representing just 'imagination' (in the sense of non-reality). Social imaginary significations are very real in their effectiveness; they 
correspond to the central societal values (beliefs, myths and world views ... ) which furnish a 'meaning' to the world of each particular society and which shape the psyche of individuals (see Castoriadis, 1975).

2. 'Social and economic inequalities are to be arranged so that they are both: (a) to the greatest benefit of the least advantaged ... and (b) attached to offices and positions open to all under conditions of fair equality of opportunity' (Rawls, 1972, p. 302).

3. Porto Alegre's participatory budgeting has inspired similar experiences not only throughout the country, but also outside Brazil: for instance, in Montevideo since 1990.

4. The same system of proportional representation is valid for the election of delegates during the five 'thematic assemblies' which were introduced later with the purpose of ensuring a comprehensive treatment of questions which are relevant to the city as a whole. The thematic assemblies cover the following themes: economic development and taxation; health and social welfare; education, culture and recreation; traffic and transportation; and spatial organisation and urban development.

5. Detailed descriptions of the process of participatory budgeting in Porto Alegre can be found in Navarro (1996) and Fedozzi (1997).

6. On this point, see Souza (1998); see also Souza (1993a). This criticism, as well as this consciousness regarding the relevance of the socio-political factors, evolved from my former research experience with urban social movements in Brazil (see, for example, Souza, 1993b).

\section{References}

Abers, R. (1998) Do clientelismo à cooperação: governos locais, políticas participativas e organização da sociedade civil em Porto Alegre, Cadernos IPPUR, January/July, 47-78.

Adams, D. (1994) Urban Planning and the Development Process, London: UCL Press.

Arnstein, S. (1969) A ladder of citizen participation, Journal of the American Institute of Planners, 35, 216-224.

Castoriadis, C. (1975) L'Institution imaginaire de la société, Paris: Seuil.

Castoriadis, C. (1978) Technique, in: Castoriadis, C. Les carrefours du labyrinthe, Paris: Seuil, 221-248.

Castoriadis, C. (1983) Introdução: socialismo e sociedade autônoma, in: Castoriadis, C. Socialismo ou barbárie. O conteúdo do socialismo, São Paulo: Brasiliense, 11-34.

Castoriadis, C. (1985) A questão da história do movimento operário, in: Castoriadis, C. A experiência do movimento operário, São Paulo: Brasiliense, 11-78.

Castoriadis, C. (1986a) Nature et valeur de l'égalité, in: Castoriadis, C. Domaines de l'homme-Les carrefours du labyrinthe II, Paris: Seuil, 307-324.

Castoriadis, C. (1986b) La polis grecque et la création de la démocratie, in Castioriadis, C. Domaines de l'homme-Les carrefours du labyrinthe II, Paris, Seuil, 261-306.

Castoriadis, C. (1990) Pouvoir, politique, autonomie, in: Castoriadis, C. Le monde morcelé-Les carrefours du labyrinthe III, Paris: Seuil, 113-139.

Castoriadis, C. (1996a) La démocratie comme procédure et comme régime, in: Castoriadis, C. La montée de l'insignifiance-Les carrefours du labyrinthe IV, Paris: Seuil, 221-241.

Castoriadis, C. (1996b) Imaginaire politique grec et moderne, in: Castoriadis, C. La montée de l'insignifianceLes carrefours du labyrinthe IV, Paris: Seuil, 159-182.

Castoriadis, C. (1997) Fait et à faire, in: Castoriadis, C. Fait e à faire-Les carrefours du labyrinthe V, Paris: Seuil, 9-81.

Castoriadis, C., Rouanet, S.P., Chauí, M., Torres, J.C.B. and Rosenfield, D. (1992) A criação histórica, Porto Alegre: Artes e Ofícios.

Daniels, N. (1975) Equal liberty and unequal worth of liberty, in: Daniels, N. (ed.) Reading Rawls. Critical Studies on Rawls' A Theory of Justice, Oxford: Blackwell, 253-281.

Doyal, L. and Gough, I. (1994) Teoría de las necesidades humanas, Barcelona: ICARIA and FUHEM.

Fedozzi, L. (1997) Orçamento participativo. Reflexões sobre a experiência de Porto Alegre, Porto Alegre: Tomo Editorial/Federação de Órgãos para Assistência Social e Educacional (FASE)/Instituto de Pesquisa e Planejamento Urbano e Regional da Universidade Federal do Rio de Janeiro (IPPUR).

Habermas, J. (1981) Theorie des kommunikativen Handelns, Frankfurt am Main: Suhrkamp, 2 vols.

Habermas, J. (1990) Discourse ethics: notes on philosophical justification, in: Habermas, J. Moral Consciousness and Communicative Action, Cambridge, MA: MIT Press, 43-115.

Healey, P. (1995) Discourses of integration: making frameworks for democratic urban planning, in: Healey, P., Cameron, S., Davoudi, S., Graham, S. and Madanipour, A. (eds) Managing Cities. The New Urban Context, Chichester: John Wiley and Sons, 251-272.

Healey, P. (1996) Planning through debate: the communicative turn in planning theory, in: Campbell, S. and Fainstein, S. (eds) Readings in Planning Theory, Oxford: Blackwell, 234-257. 
Healey, P. (1997) Collaborative Planning. Shaping Places in Fragmented Societies, Basingstoke: Macmillan. Healey, P. (1998) Collaborative planning in a stakeholder society, Town Planning Review, 69, 1-21.

Held, D. (1996) Models of Democracy, Stanford, CA: Stanford University Press, 2nd edition.

Innes, J. (1995) Planning theory's emerging paradigm: communicative action and interactive practice, Journal of Planning Education and Research, 14, 183-190.

McConnel, S. (1995) Rawlsian planning theory, in: Hendler, S. (ed.) Planning Ethics. A Reader in Planning Theory, Practice and Education, New Brunswick, NJ: Center for Urban Policy Research, 30-48.

Navarro, Z. (1996) 'Participatory budgeting' — the case of Porto Alegre (Brazil), paper presented to regional workshop: Decentralization in Latin America-Innovations and Policy Implications, Caracas, 23-24 May.

Rawls, J. (1972) A Theory of Justice, Oxford: Clarendon Press.

Ribeiro, L.C.Q. and Cardoso, A.L. (1990) Plano diretor e gestão democrática da cidade, in: Grazia, G. de (ed.) Plano diretor: instrumento de reforma urbana, Rio de Janeiro, Federação de Órgãos para Assistência Social e Educacional (FASE).

Souza, M.L. de (1993a) Reflexão sobre as limitações e potencialidades de uma reforma urbana no Brasil atual, Actas Latinoamericanas de Varsovia, 15, 207-228.

Souza, M.L. de (1993b) Armut, sozialräumliche Segregation und sozialer Konflikt in der Metropolitanregion von Rio de Janeiro, Tübingen: Selbstverlag des Geographischen Instituts der Universität Tübingen.

Souza, M.L. de (1996) A teorização sobre o desenvolvimento em uma época de fadiga teórica, ou: sobre a necessidade de uma 'teoria aberta' do desenvolvimento sócio-espacial, Território, 1, 5-22.

Souza, M.L. de (1997) Algumas notas sobre a importância do espaço para o desenvolvimento social, Território, 3, 13-35.

Souza, M.L. de (1998) Desenvolvimento urbano: a problemática renovação de um 'conceito'-problema, Território, 5, 5-29.

Stone, C. (1993) Urban regimes and the capacity to govern: a political economy approach, Journal of Urban Affairs, 15, 1-28. 